\title{
JUS AD BELLUM AND INTERVENTION IN SOMALIA: WHY A MILITARY RESPONSE CAN STILL WORK
}

\author{
John Stupart \\ Associate Researcher - Executive Research Associates (ERA)
}

\begin{abstract}
Somalia has suffered a rupture. Following the failed United Nations Operation in Somalia (UNOSOM) interventions to stabilise the failed state, few state leaders or military organisations consider serious intervention. The research on which this article is based, sought to provide a theoretical foundation for reintervention into Somalia using "just-war" theory, particularly that of jus ad bellum. By highlighting how intervention is just, feasible and legitimate when employed through the right channels and within the right strategic framework, this article reports on ways in which the hypothetical stabilisation of Somalia can be achieved realistically, should the political will ever emerge. The lessons of UNOSOM are not necessarily valid anymore, and as such the research reported here examined the problem of Somalia on the basis that intervention need not result in another Blackhawk Down. ${ }^{1}$
\end{abstract}

\section{Introduction}

The failed state of Somalia is seen as a lost cause internationally. With clanbased conflict waging across the failed state, the recent post-2005 surge of piracy off

Scientia Militaria, South African

Journal of Military Studies, Vol 39, Nr 2, 2011, pp. 76-98. doi: $10.5787 / 39-2-112$ the coast and constant political upheaval between the internationally recognised Transitional Federal Government (TFG) and various hard-line Islamic groups such as the Council of Islamic Courts (ICU) or Al-

${ }^{1}$ Blackhawk Down refers to a 3 October 1993 operation in which 19 US servicemen were killed on a mission to capture key Habr Gidr clan leaders, as well as the shooting down of two Blackhawk helicopters. The battle in Mogadishu was the bloodiest since the Vietnam war and was only superceded by the Battle of Fallujah in 2004. Swiftly following the battle, the US mission in Somalia began to unravel, with an eventual withdrawl in 1994. 
Shabaab, Somalia is a veritable cornucopia of insecurity. ${ }^{1}$ With the intervention of the United Nations in Somalia in the early 1990s having been a colossal failure in terms of conflict prevention and resolution, precious little effort has been made other than World Food Programme shipments being transported regularly through the pirate-infested waters. ${ }^{2}$ There is a permeating atmosphere of hopelessness about Somalia, both in how to secure it and in how to conduct any manner of long-term development. But this need not be the case. There is a two-staged approach as to just why Somalia is worth saving and - most importantly - how the precedents of UNOSOM I and UNOSOM II, as well as other engagements in the failed state, are strategically flawed in justifying non-intervention in a twenty-first century security environment. $^{3}$

Another military intervention, with a lead actor such as the United States or other NATO member under a UN or AU (or joint) framework, is feasible, legitimate, and justified when utilising Grotius' historically rich "just-war" theory to better understand the strategic landscape of Somalia. Examining why the "justice for war" or jus ad bellum principle for intervention exist, according to this theory as well as International Law is valid will enable justification for any future intervention. ${ }^{4}$ Understanding that intervention is at least morally acceptable according to one of the oldest military ethical codes in existence enables a better perspective on analysing Somali intervention.

The first issue worth considering is whether full-scale military intervention is strategically feasible must then feed into any serious consideration for intervention. Secondly, it is important to explore whether intervention can contribute meaningfully to the post-conflict development of Somalia as a whole, and not just in central areas such as Mogadishu. The final component is the "humanitarian" aspect of intervention. Solving Somalia's multitude of developmental challenges requires a sustainable, long-term solution, together with the ability to create some manner of agency within the long-divided clan culture of Somalia. Furthermore, very similar to the military portion of any perceived intervention in the twenty-first century, the feasibility of humanitarian intervention in Somalia is equally important.

Initial intervention in Somalia in the early 1990s was conducted with questionable strategic and operational efficiency under USA/United Nations (UN) command. Indeed, the Blackhawk Down disaster on 3 October 1993, which precipitated a massive UN withdrawal from Somalia as a whole, and the subsequent overall failure of the mission, could have been avoided entirely if the security challenges of Somalia had been dealt with in a more realistic, considered light. ${ }^{5}$ Given the lessons that America and its coalition allies have learned in Operations 
Iraqi Freedom and Enduring Freedom, as well as from the UN's ongoing efforts in Africa since UNOSOM, a return to evaluating just how to go about restoring Somalia as a state should be considered from a broad perspective. If a Chapter VII intervention or similar coalition-based operation is feasible, then the only true obstacle to re-aligning a country gone awry is that of political will, which is in itself entirely subject to change. If Somalia's development can be achieved in a sphere of successfully induced peace, then there is the potential for it to remain tenable in the short term.

\section{A case for intervention - the military track}

Since the UN's departure in 1995 following the failure of UNOSOM I and II, Somalia has suffered virtually constant civil war at the hands of several clan warlords vying for their own segment of power in the region. ${ }^{6}$ The collapse of Siad Barre's regime at the hands of rebels in 1991 effectively signalled the beginning of the end of any semblance of stability in Somalia. ${ }^{7}$ With Mohammed Aideed and Ali Mohamed Mahdi waging vicious war on the streets of Mogadishu, not excluding the scores of smaller clans who had allied themselves with one or another patron warlord, the UNOSOM I mission was deployed to enforce a Chapter VII mandate against both parties in Mogadishu and surrounds, effectively attempting to enforce a ceasefire. ${ }^{8}$ However, by the time UNOSOM II was authorised by the SecretaryGeneral in order to ensure the distribution of food aid and disarmament measures throughout Somalia as a whole, Aideed was ultimately responsible for refusing to accept negotiations, preferring instead to continue hostilities against political rivals and UN forces in general. ${ }^{9}$ With an independent American Ranger and Quick Reaction Force (QRF) operating within Somalia independently in order to detain Aideed himself and his staff, the Blackhawk Down disaster of 3 October 1993 ultimately precipitated an international crisis. When militia forces paraded a dismembered American body through the streets of Mogadishu, the televised message that hit home had far-reaching consequences. ${ }^{10}$ What was initially an unknown UN-sanctioned attempt at feeding and stabilising a starving nation amid a civil war resulted in a tremendous outcry from Americans back home at the witnessing of such graphic violence against their countrymen. What subsequently resulted was the withdrawal of US forces from the region and the breakdown of the UN humanitarian mission surrounding it. In the case of Somalia, not only was the premise for the military intervention justified by the United Nations, the American public's support of the mission remained strong up until 3 October. 
In the twenty-first century, the virtual abandonment of Somalia by the international community since the withdrawal of UNOSOM in 1995 has seen the state effectively dissolve, with the region splitting into three semi-autonomous zones: Somalia is ostensibly ruled by the internationally recognised Transitional Federal Government (TFG) in the south and, technically, Mogadishu, Puntland in the central region of the horn of Africa, and the most stable, unrecognised area of Somaliland. ${ }^{11}$ In reality however, the TFG has been mostly marginalised while al Shabaab control most of the country south of Mogadishu, with pirate leaders maintaining power in Puntland. The emergence of piracy off Somalia's coastline since and the surge in attacks at sea has created an entirely new set of transnational security threats in the Gulf of Aden. ${ }^{12}$

With the emergence of piracy, the underdevelopment of Somalia serves to provide a perpetual source of volunteers who will eagerly replace those captured or killed in the Gulf of Aden. Ultimately, the inability of Somalia to govern itself and secure its own ocean territory must factor into any policies aimed at curbing piracy. Essentially, the problems facing Somalia can be contained within three categories.

Firstly, there is the problem of political instability at the hands of warring clans, Islamist organisations and separatist Somaliland regional leaders. Secondly, the humanitarian requirements of Somalia run the gamut from insufficient food aid, medical care, and the erroneous distribution networks thereof. Lastly, and perhaps most critical to the first part of this problem, there is the immense security challenge that Somalia poses to the international community as well as to regional neighbours such as Ethiopia, Djibouti and Kenya.

On the one hand, there is the civil war raging on from Puntland to Kismayo between warlords, TFG troops and islamist groups, with no end in sight. On the other side there is the emergence of piracy as a major scourge in the seas of the Gulf of Aden. Consequently, securing Somalia is of the utmost importance in order for any meaningful humanitarian assistance and long-term post-conflict development to take place. This is not to say that doing so would be an easy task.

The military feasibility of and justification for intervening in Somalia can be examined utilising the historically rich "just-war" theory. With historical roots going as far back as the classical Greek and Roman philosophers, as well as prominent Christian thinkers such as Augustine and Thomas Aquinas, "just-war" theory has an extremely rich theoretical background. ${ }^{13}$ Furthermore, contemporary thought has not neglected this theory on the whole. Michael Walzer, perhaps the foremost modern contributor to "just-war" theory, has provided much revision to the broader notions 
of "just-war" theory. The theory, broadly speaking, aims to provide a set list of criteria for what one could use to evaluate whether or not a war, campaign or occupation was "just". It is important to note that "just-war" theory is almost exclusively a philosophy stemming from Western and, later, Christian theological schools of thought. ${ }^{14}$ As such, "just-war" theory bears credibility purely in the modern westernised sense. Given the rise of anti-western conflict in the world, it is important to recognise this distinction from the outset as "just-war" theory does not reflect the morality of any army or military waging war.

Thus "just-war" theory still has a significant influence on the justifications states and international military organisations use in their own campaigns. Although the tactics and nature of warfare have changed considerably on the ground, justifications for the war in the first place still remains necessary in modern world politics.

"Just-war" theory possesses three core categories for the moral evaluation of a war: Jus ad bellum, the justice of going to war in the first instance; Jus in Bello, the justice in the combat and conduct of the war, and lastly Jus post bellum, the justice of post-conflict proceedings. ${ }^{15}$ Each of these categories possesses a clear list of criteria for what makes the cause, conduct and post-conflict management of a war just.

In the context of Somalia, the justice during the conflict and after will be relatively assured, given that western, democratic militaries by and large try to adhere to the principles of international laws on war, particularly those of the Geneva and Hague conventions. While discrepancies certainly exist in contemporary asymmetrical theatres of conflict, the restraint with which modern Western armies wage war is undeniable, particularly when compared with other large militaries' conduct in modern warfare. This distinction is important as it highlights the dual methods by which one can evaluate the "justice" of a war, exemplified in the "Rommel dilemma" argued by Walzer: "Though Rommel was engaged in a manifestly unjust war, he invariably and scrupulously adhered to the rules of war, and refused to obey Hitler's orders to violate them."16 Thus, according to Walzer, a lack of justice in one area of "just-war" theory does not necessarily constitute complete injustice overall. Even if it were not permissible as an a priori assumption, the potential for arguing a "double judgement" as envisioned by Walzer ensures that justifying a case for intervention in Somalia is in no significant way impeded by the subjective assumptions on the conduct of forces during and after the fighting ceases. ${ }^{17}$ But in order to actively engage in military intervention in Somalia, jus ad 
bellum criteria must be examined in detail. These criteria are as follows, and will be examined systematically in the Somali context:

- just cause

- right intention

- proper authority

- last resort

- probability of success

- proportionality.

A "just-war" theory application of jus ad bellum can be framed in the more contemporary notion of "responsibility to protect" (R2P), particularly when one considers how much the two doctrines overlap in purpose. ${ }^{18}$ At the 5858th meeting of the UN Security Council, the notion of the responsibility for the international community to intervene was discussed, as the advisor to the Secretary-General urged for the intervention in both political and security tracks, in the hopes of fulfilling the obligations set forth behind the spirit of R2P. ${ }^{19}$ Somalia has historically failed to protect its own people from self-destruction since the early1990s; thus the burden or responsibility of intervention lies squarely on the shoulders of the international community since it is in accordance with a morally-acceptable justification for military force.

\section{Just cause}

Gareth Evans and Mohammed Sahnoun justified military intervention in the modern framework of R2P through analysis of what the just-cause threshold shall be before the UN or in extraordinary cases a coalition of sovereign states intervenes. ${ }^{20}$ In the tradition of Grotius' philosophy, just causes for war can effectively be reduced to three overarching grounds: when acting in self-defence, when defending others from attack and when protecting citizens from oppressive, violent regimes. In the twenty-first century, this can include the just cause of situations of "state collapse and the resultant exposure of the population to mass starvation or civil war, as in Somalia." 21 The TFG may be defined as the legitimate authority, at least politically, but the underlying truth remains that Somalia is without legitimate state control. Because of Somalia's anarchic nature the citizens are not being threatened and oppressed by a single violent regime, but by several smaller clans and armed militias. This, if anything has proven to be more detrimental than a single, despotic government or leader. Indeed, if anything, the cause for R2P in Somalia is only strengthened by its anarchy. 
Considering the undeniably chaotic state of Somalia, the TFG is unable to protect its own citizens from harm, whether through overt violence from al Shabaab, Hizbul Islam or any number of warring clans, or from famine-induced human security problems. Considering this inability by the Somali Government to protect its population from harm, R2P and "just cause" are fully satisfied for an intervening power.

It is difficult to exaggerate the suffering which Somalis have endured for decades in order to absolve international actors from action. However, when one examines the perpetual violence of Somalia's clans, together with the sheer number of lives lost to the fighting, combined with endemic drought and insufficient food aid which is threatened by the scourge of piracy anyway, the case for legitimate intervention becomes clear. ${ }^{22}$ Likewise when one considers that a million Somalis are internally displaced, the human security threats become self-evident. ${ }^{23}$ Lastly, it is crucial to consider anticipatory action as justified in order to avoid greater human disaster:

Military action can be legitimate as an anticipatory measure in response to clear evidence of likely large-scale killing or ethnic cleansing. Without this possibility, the international community would be placed in the morally untenable position of being required to wait until genocide begins before being able to take action to stop it. $^{24}$

The one primary difficulty in analysing Somalia's case, however, is that the stateless country suffers more from a prolonged and chronic manner of human suffering rather than outright genocide or ethnic cleansing. But when the continuation of mass starvation and hopelessness borne from complete state collapse and failure is considered, it is completely within the just cause criteria threshold to consider intervention.

The justification for intervention is self-evident. But we have not seen a major operation like that of Operation Restore Hope since. "Just cause" is thus not the reason why there is no serious attempt at stabilising Somalia. This has bearing in modern international relations, where states (or even coalitions of states) are reluctant to involve their military forces on the grounds of lacking justification. Before R2P, refusing to acknowledge the need for intervention in a humanitarian crisis was enough to satisfy inaction. But when a state has imploded, and is no longer capable of protecting its citizens, “just cause" principles align completely with R2P 
guidelines, where state sovereignty is determined less by sanctified geographic borders and more by a government's ability to protect its citizens. In the $21^{\text {st }}$ century strategic landscape of Somalia the real question of why there has been no concerted effort at stabilising the country is not whether it would be "just" so much as whether it is feasible.

\section{Right intention}

The right intention, contrary to the just-case intention, for going to war is an aspect which cannot normally be substantiated with any legally useful evidence, and as such is excluded from international law as a requirement. ${ }^{25}$ Stated simply, any intervening state or institution must have only the intentions of the stated objective at heart, rather than ulterior motives such as economic or territorial acquisition. In the Horn of Africa, a good example of this would be that of Ethiopia's continuing strategic interests in the region.

Given the Ethiopian invasion in 2006 to oust the then ICU, it stands to reason that this nation could not take a leading role in any humanitarian intervention under the aegis of R2P. ${ }^{26}$ In order for some semblance of right intention to be assured in a deployment to Somalia, a non-neighbouring leading state would have to take central role, be it through UN approval or otherwise - another aspect of jus ad bellum which will be discussed in further detail in the next criterion. The current criterion is ultimately outdated in modern international law and the behaviour of states since it would be impossible to prove the real Ethiopian intent in a hypothetical intervention, even though its strategic aims with regards to Somalia are clear.

Given that any major intervention in Somalia would probably involve major states such as the United States, who is actively mounting counter-terror operations in the Horn of Africa already, or NATO members likewise pursuing divergent objectives, it is crucial to ensure that, although one cannot truly identify the "intention" alignment of states involved, they can at least be in accordance with the reasoning or "just cause" behind the mission itself. ${ }^{27}$

\section{Proper authority}

Evans and Sahnoun rightly assert that the criterion of "proper authority" is the most important albeit controversial criterion in determining jus ad bellum for R2P intervention. ${ }^{28}$ Since the United Nations, or rather the Security Council, should be heavily involved in any manner of intervention in Somalia, along with the AU, both 
in the military and post-conflict humanitarian decision-making and operations, it follows that these organisations would be the highest authority in matters as important as enforcing something like the intervention in Somalia.

However, of key importance is the problem of the Security Council's potential failure to act when the need is both clear and justified, as has been the case before in other instances of crisis such as the Rwandan genocide or, more recently, within the Ivory Coast. ${ }^{29}$ When intervention is both feasible and justified, yet is nonetheless denied by Security Council members, the credibility of the United Nations is ultimately undermined by inaction. In 1999, when the Security Council failed to intervene in Kosovo, for example, NATO embarked on its own independent intervention, headed by the NATO-led Kosovo Force (KFOR forces). ${ }^{30}$ The intervention was arguably a success in the sense that it did begin to bring about a cessation of hostilities between the warring parties, and ironically lay a good foundation for the UN's subsequent involvement through Resolution 1244, which has subsequently seen Kosovo not only recovering from the conflict, but ultimately declaring independence. ${ }^{31}$

The recent imposition of a no-fly zone (NFZ) in Libya, in accordance with United States Security Council (UNSC) Resolution 1973, has proven that intervention, even if only from the air (and sea), greatly legitimises the UN's ability to determine just when intervention is or is not justified. With UNSC approval, and an explicit mandate to protect civilians from loyalist (and technically rebel) forces, intervention can be used responsibly. There will naturally be objectors, neutral parties, or opponents to intervention, as evidenced by the five abstentions in the UNSC for Resolution 1973; but with a UN-recognised majority vote, it is possible to achieve a high degree of consensus on when and when not to intervene. ${ }^{32}$ Such intervention will be neither perfect nor equally-dispensed, but at least it will be lawful in terms of international law when the mandate is implemented.

Should the case for intervention be clear, yet the political will in the Security Council be absent, multilateral organisations or coalitions of the willing can and should play a pivotal role in preventing conflict. ${ }^{33}$ If alternative organisations or states are not petitioned in the event of Security Council failure, this then runs the risk of enabling powerful states essentially to ignore with the UN's seal of approval whichever state is in collapse or erupting in conflict. The responsibility to protect should not be a subjective principle at the behest of Security Council resolutions, which can potentially become heavily influenced by non-essential political interests or agenda. Instead, it should be the first port of call in the outbreak of emergency 
and, similar to the Kosovo precedent, be able to assist when member states eventually decide to act.

The UN aid missions to Somalia in the early 1990s have set an example in the sense that intervention into the failed state was both acceptable and had been encouraged before. It is not unfair to argue that Somalia in the 21st century has not improved measurably since UNOSOM failed, and thus the authority with which intervention was decided upon then still exists.

\section{Last resort}

Naturally, mounting a military intervention should not be the first option when deciding on how to resolve a conflict. Intervention according to jus ad bellum is only permissible when all other plausible, peaceful measures have been taken. ${ }^{34}$ Unfortunately, in the case of Somalia, many of the avenues of peaceful coercion open in interstate conflict, such as diplomacy, negotiations, and sanctions, simply do not exist or cannot be feasibility employed. This is in no small measure due to the fact that Somalia is essentially a collapsed state. ${ }^{35}$ While the TFG does enjoy international recognition as the legitimate government of Somalia, the reality is that precious little of Somalia is effectively governed by anyone, let alone the TFG.

One of the larger problems of UNOSOM was the attempt to implement negotiations with warlords, militants and politicians, and simultaneously to gain a ceasefire agreement and subsequent disarmament across the board. Ironically, that these smaller mediations took place in Mogadishu at all was a direct result of the UN failing to find any other solution. ${ }^{36}$ The beginnings of UNOSOM I was thus a "last resort" after exhausting normative means of conflict resolution without military intervention. Considering lack of meaningful progress since the 1990s, the criterion of "last resort" can and does still apply today when justifying military intervention. The same criterion as for proper authority?

\section{Probability of success}

Somalia has been ignored as a worthwhile endeavour in terms of R2P or any meaningful intervention precisely because it has been perceived as a "problem child" without military a solution - an entity which is largely forsaken in its multiplicity of problems which cannot be solved in any long-term manner by the international community. With the failure of Operation Gothic Serpent (the objective of which was to capture Aideed himself), as well as the general ineffectiveness of UNOSOM 
II to ensure peace and stability while distributing aid, military intervention has not been seriously considered since, with the possible exception of The EU Naval deployment in the Gulf of Aden (Combined Task Force 151) whose presence in limited counter-piracy operations off the Somali coast has produced some stability at sea. ${ }^{37}$ The probability of success - of meeting objectives laid out in the context of overall humanitarian intervention envisioned in just post bellum, such as peace enforcement, conflict resolution, Disarmament, Demobilisation and Rehabilitation (DDR), and humanitarian aid - is minimal at best. With the death of 25 Pakistani UNITAF (Unified Task Force) peacekeepers in Mogadishu in 1993, and the subsequent 3 October "Battle of Mogadishu" in which 18 American soldiers and approximately 1000 Somalis were killed, it is presumed that even when the United States brought its military force (including highly-trained special forces) to bear on the conflict, the Somali militia were unbeatable. ${ }^{38}$ However, there are several mitigating factors in 1993 which can provide a valid counter-argument to this assumption. Moreover, the "probability for success" is the single most important obstacles to be overcome in the Somali context, as it is generally considered utterly unfeasible to intervene in significant force given the historical precedent.

Proponents of the African Union Mission in Somalia (AMISOM) may suggest that the African Union's (AU's) current effort in peacekeeping is the one major intervention which has achieved some measure of success. But AMISOM is facing fierce resistance from Al-Shabaab insurgents, suffering considerable casualties, and ultimately casting the probability of success of AMISOM's mission into serious doubt. As of the start of 2011, AMISOM have suffered over 300 fatalities during operations in Somalia, largely due to insurgent attacks. It has been several years since AMISOM was launched, and there is as yet no broad stability throughout Somalia and therefore no secure channels for aid distribution. At a force strength now of just over 8000 , the peacekeepers should not be blamed for this failure because they simply lack the capability to do anything more permanent. Indeed, there is very little concrete indication that the AMISOM mission has a reasonable probability of success in its current form. Without increased troop numbers, pacifying Al-Shabaab and their insurgents, and enabling meaningful aid to reach those in need (and not the black market), are not attainable. ${ }^{39}$

The probability of success during UNITAF's presence in Somalia was severely hampered by the sheer lack of boots on the ground. With an initial deployment of just one battalion of Pakistani blue helmets in October 1992, and the remainder of UNOSOM's state interveners holding back on their promises of sending troops, the initial presence of peacekeepers was woefully inadequate. ${ }^{40}$ Ironically, Sahnoun, who had witnessed the UNOSOM operation from the ground, 
had advocated for even 500 more troops to make an impact: "There is no doubt that had these 500 troops been fully deployed as late as a month after the agreement, that is, at, the beginning of September, it would have made an appreciable difference." ${ }^{\text {,1 }}$ However, given the turmoil in Somalia, combined with the immense looting of food aid comprising officially of $10-15 \%$ of delivered goods, it is difficult to perceive just why such a small complement of additional troops would have made any tangible difference at all. ${ }^{42}$ Even at the end of 1993, with the general failure of restoring peace to Somali, there was simply insufficient numbers of troops to manage the tasks laid out by the UN.

Moreover, the actual strategic purpose of intervention in Somalia mutated significantly over the period in which UN forces were actively involved in the country. While the Secretary-General had accepted the option (endorsed by the Security Council in Resolution 794) of a major, US-led “enforcement operation” also under American command, the initial objectives were almost immediately altered by Boutros-Ghali. ${ }^{43}$ What had been stressed by President Bush as a limited, near-term operation designed to keep the channels of food-aid open and secure, almost immediately was warped in concept by the Secretary-General:

American forces entered Somalia on December 9. Later that day, however, the secretary-general told a delegation from Washington sent to brief the secretariat that he wanted the coalition not only to disarm all of the Somali factions, but also to defuse all mines in the country (most mines were in the secessionist north), set up a civil administration and begin training civilian police. ${ }^{44}$

This inability to establish a clear strategic path forward in the usage of military forces is crucial when evaluating the probability of success in a region. In Somalia, the objectives of the military forces were never unanimously coherent outside of the Resolution's papers, and this fed directly into the initial misunderstanding. While state leaders are effectively responsible for this lack of cooperation, the same phenomena can easily be repeated by institutions in which state leaders operate.

When President Clinton took over from Bush, the mission in Somalia warped further, ultimately providing one major obstacle to any tangible success in Operation Restore Hope. With Clinton came the beginnings of "assertive multilateralism” and the notion of not just keeping open the channels for food aid, but to encourage the broader ambit of nation-building and development as a whole. ${ }^{45}$ This was not the original intention for UNOSOM forces, nor was it effectively able to respond to the 
mounting violence on the streets of Mogadishu and surrounds. Effectively, Clinton's almost ad hoc dabbling with foreign policy shifts manifested itself in a strategic quagmire in Somalia:

The administration immediately reached for new options, deciding to double the total American military presence in Somalia and offshore, while announcing the intention to withdraw entirely by March 31, 1994. "Nation building" had thus become a desperate search for a face-saving American withdrawal, exactly one year after Americans would have departed under President Bush's original plan. ${ }^{46}$

If the reasonable probability of success for a contemporary intervention is to be seriously considered, it is important to take heed of the above mistake committed by the change of presidents and foreign policy in the United States. As the leading state actor is cooperating with a UN task force, any large-scale intervention would require an initial strategic evaluation of which objectives are attainable with the forces available, as well as a clear and coherent timetable. Certainly some aspects of the operation are subject to change according to the process of the conflict resolution. Ending conflict is by no means hard and fast, but it can certainly be assessed more coherently if a state's foreign policy shift does not translate directly into an ongoing mission.

Finally, and perhaps one of the most important (and arguably overlooked) factors in determining probability of success is the actual make-up of the military forces being deployed. According to the Powell Doctrine and the use of American forces abroad, military forces should, if it cannot be avoided (that is, war as a "last resort”), be deployed massively and decisively, and with a clear set of objectives in addition to a feasible exit-strategy. ${ }^{47}$ Without these, military interventions run a relatively high risk of becoming incoherent, messy strategic quagmires from which states scramble to forget and never repeat while undermining the power of the leading state in question. ${ }^{48}$ The coalition learned this lesson again the hard way in Iraq, and AMISOM is fast comprehending the enormity of the task it has chosen to undertake, using a model (Burundi's intervention) that is not adequate in force for Somalia.

The UN mission, including the US forces, consisted of what on paper could be argued to have been a formidable force but effectively lacked any of the tools, numbers and Rules of Engagement required for the task of securing what is one of the least secure states in the world. The "tip of the spear", that is the US forces in Operation Gothic Serpent, comprised various infantry companies, including elite 
Army Rangers and DELTA Force operators (that is, Special Forces.) However, their operations were conducted in thinly armoured vehicles, trucks and helicopters. The distinct lack of powerful weaponry, while making the UN mission appear less hawklike in international media circles, crippled the operational capabilities of the forces on the ground. Without fixed-wing aircraft and armoured vehicles, tanks and any form of indirect fire support such as mortars or artillery, the forces on the ground were woefully under-equipped to fight the thousands of warring militia on the ground in the tightly packed streets of Mogadishu. ${ }^{49}$

A recent example of the capability to pacify parts of Somalia lies ironically in one of the region's most controversial organisations (or currently former organisation.) The Supreme Council of Islamic Courts, better known now as Islamic Courts Union (ICU), effectively managed to eradicate piracy altogether during its six-month reign of power by attacking the pirate "haven" ports and aggressively rooting out pirates on land and at sea. ${ }^{50}$ This was achieved, not because the ICU saw piracy as a reprehensible breach of international law or Islam, but rather because the pirate warlords were political enemies. Once the TFG, backed by Ethiopian troops, wrested power from the ICU in late 2006, however, piracy surged once more as the TFG's control over the country lapsed south, leaving Puntland once again to the pirates. ${ }^{51}$ Essentially then, Somalia can indeed be pacified if sufficiently aggressive action is taken.

Certainly, such an upscale in weapons and destructive capability flies in the face of Clinton's spirit of American foreign policy, as well as the objectives (however muddled) of the UNOSOM mission and its execution. But herein lies the crux of the matter: if one truly wishes to apply R2P in Somalia, a state that is extremely volatile, violent and unruly, a long-term security net needs to be established in order to ensure the stability of post-conflict aid and development which can then proceed in relative peace and quiet.

This massive scale of operations is not unprecedented in terms of peace operations. The KFOR task force commanded by NATO comprised a holistic military deployment of multinational forces, as well as extensive air and land support thereof. If commanders and state leaders are realistic upfront about the strategic requirements of committing forces to an intervention, then there is every possibility that success can be achieved. But the permeating attitude remains that Somalia is a strategic problem whose solutions are not yet evident. This is almost a psychological phenomenon in the post-Iraq and Afghanistan military world, in the sense that what was, and still is, perceived as an impossible military task really is not. 
The UNOSOM failures of 1993, in which both American and Pakistani peacekeepers were killed, while tragic, is by no means an indication of the impossibility of a successful military intervention today, though it is often trumped as a major excuse for non-intervention in the twenty-first century. Indeed, US policymakers have been reluctant since the 1993 disaster to get involved in land battles in the Horn of Africa. Even though this initial flashpoint was by no means decisive, the US forces actually achieved their objective of capturing several of Aideed's aides on 3 October, and the tools required for the job, such as armoured personnel carriers, fixed-wing air support and artillery, was never seriously considered. $^{52}$

A holistic strategy for a success would require several measures: a "massive deployment" in accordance with the Powell Doctrine, clear and coherent objectives from the outset, a strong naval presence in the Gulf of Aden to curb piracy, aggressive Rules of Engagement, and military depth. Such an intervention force would not just consist of infantry, but all the necessary aspects of waging a largescale military operation against a hostile enemy force. This is in accordance with the Powell Doctrine and would be effective in creating a stable Somalia for post-conflict development and aid operations. It may seem excessive to have more than lightly armed infantry operating under the auspices of humanitarian intervention, but one must bear in mind that Somalia is an exceptional case. Understanding the true threats in Somalia will help in gauging the proportionality required in this regard.

\section{Proportionality}

The ultimate utility of the war is the expectation that going to war will yield a net-positive result for both sides involved, with one major factor being the number of casualties. ${ }^{53}$ Intervention in Somalia must be done not only to address the injustices being committed on the ground - that is, mass starvation and state collapse in Somalia - but it must also be a considered evaluation of whether or not Somalia will be better off after hostilities cease.

Given that the entire purpose of military intervention in Somalia would be to create a security net in which UN organs can provide humanitarian aid and, if the scope and budget allows, promote the large-scale political and economic development of Somalia, it is not unreasonable to assert that the perceived net benefit would more than outweigh the decades of misery that have plagued Somalia. Moreover, if the probability of success exists, as previously argued, it is crucial to think of a post-conflict Somalia as a distinct possibility, with a stabilised foundation 
for facilitating mediation between uniting factious clans and militants on a meaningful, securitised basis.

The above failures in the intervention in Somalia in the 1990s raise serious objections to the effectiveness of international peacekeeping. Given the scope and length of UNOSOM I \& II, as well as the US leadership taken in attempting to provide aid to a nation starving itself, it is easy to get the impression that a second military intervention, for whatever purpose or objective, would be foolhardy at best. But when one applies a sober analysis of the conflict itself, as well as the nature in which the initial operation was conducted, this is not quite the case. With the proportionate amount of military assets in terms of boots on the ground, and the firepower necessary to quell the chronic violence that plagues Somalia, it is entirely possible to securitise Somalia relatively quickly if carried out with a modicum of strategic responsibility.

Finally, while the jus ad bellum for intervention in Somalia is arguably justified, this is not the end-point in order to "save" Somalia. If the failed state can be pacified and peacekeeping operations commenced thereafter, there is a very real utility in military forces making a meaningful contribution in terms of maintaining stability for post-conflict development and humanitarian aid to commence. If military intervention is truly as vital as argued, the humanitarian post-conflict aspect must also be able to make a justified and meaningful a contribution to Somalia, if not the most important aspect. Restoring peace to a volatile region is one thing, but if Somalia is to be adequately and effectively stabilised in any sustainable fashion, the humanitarian track has to be just as coherent, which would fall into the realm of jus post bellum, the justice after war, thereby Ensuring post-conflict humanitarian efforts are in accordance with just war theory (and international law).

\section{The humanitarian track}

Securing a peace in Somalia is the first step in addressing some initial humanitarian assistance. That being said, however, the developmental challenges of what is the world's most failed state cannot be overcome unilaterally, quickly or even completely even, if the will existed. Patrick Lennox makes the point that Somalia's underdevelopment is the primary source of piracy, and that any comprehensive, endstate solution to piracy in the region would require stabilising Somalia as a country. ${ }^{54}$

That being said, state leaders have not completely abandoned the land of Somalia for the sake of sea-borne operations. Through the World Food Programme 
(WFP), an attempted target of 2,4 million civilians per month are provided with food aid, while the WFP humanitarian missions themselves are protected by naval escorts of various nationalities. ${ }^{55}$ Naturally, the assumption that food aid would be sufficient to solve any of Somalia's problems or even reduce them significantly is supremely naive, but it does indicate that the problems of Somalia have been completely abandoned by other states. The aid itself is often seized by local warlords or subjected to pirate attacks while transiting through the Gulf to Mogadishu, which effectively tempers any goodwill displayed by states through the WFP. If the aid mission itself needs protection from piracy, then aid clear is not providing any mitigation of Somalia's problems. While the aid would certainly be intended to prevent famine, , it is by no means sufficient in terms of international aid to Somalia if eliminating conflict is an end-goal. With an additional 2,6 million Somalis in need of food aid above the current WFP quota, the current state-sponsored action to stabilising the country is woefully inadequate. ${ }^{56}$ That said, the WFP should not be liable for Somalia's stabilisation, but the prominent role it currently plays highlights the lack of other roleplayers in the region's development.

Nonetheless, if increased humanitarian aid can be sustained, some manner of agency be created within the Somalis themselves, and if it could be proved that security is relatively assured, and precious aid resources would not fall prey to the black market, then ultimately Somalia's security challenges are not completely without solution.

\section{Sustainability}

Crucial to the humanitarian aspect of intervention is the problem of ensuring that whatever assistance is provided is not simply a stop-gap but rather a more longterm, empowering phenomenon. According to Sahnoun, this was one of the major failures of UNOSOM:

Basically, if the assistance, both military and humanitarian, had been forthcoming in the way and at the level expected in Somalia by relief-workers and Somalis, it would have contributed greatly towards creating an atmosphere propitious to dialogue and compromise. Tragically, not only was the UN assistance programme very limited, but it was also so slowly and inadequately delivered that it became counterproductive. ${ }^{57}$ 
Similar to the use of military force according to the Powell Doctrine, so must humanitarian assistance programmes also be launched on a massive scale, or not at all. To provide a token level of assistance to a country in which it is neither useful nor adequately delivered effectively erodes whatever confidence the local population may have had in the UN's ability to rescue the country. Failure to address just post bellum would ultimately detract from the entire legitimacy of any hypothetical intervention. The UN/AU must be equally committed during the stabilisation of Somalia as much as the post-conflict development of Somalia.

During UNOSOM I, before the Pakistani battalion of peacekeepers were deployed, Somali bandits raided and looted UN food aid trucks and warehouses almost at will. ${ }^{58}$ But this looting continued even afterwards due to the sheer inability to protect every single food aid shipment completely. As a result of this lack of security, thousands of Somali lives were lost, as what little assistance was being delivered was not being distributed to those most in need, but rather hoarded and/or sold on the black market. Because of this insecurity, providing humanitarian assistance to the 3,2 million Somalis in need has been drastically reduced, meaning that any semblance of sustainability will have disappeared. ${ }^{59}$ With the security net which a large-scale military intervention can provide, the threat to aid delivery and assistance can be reduced.

But simply handing out humanitarian assistance will never provide a longterm solution to Somalia's problems regardless of how prolonged and sustainable it will be. In order to progress from preventing starvation to achieving meaningful development, providing Somalis themselves with a sense of agency is of utmost importance.

\section{Empowering Somalia (social opportunity)}

If there was one characteristic feature of UNOSOM's work in Somalia, it would be the heavy, top-down approach to operationalising humanitarian assistance, opting for ceaseless negotiations with warlords and elders, and informing them about decisions made in UN boardrooms thousands of miles away. But one of the more important necessities of dealing with Somalia's fractious clan society is that of creating a sense of agency within the Somali people themselves.

According to Amartya Sen, improved political and educational capabilities better aid individuals in making more appropriate the social arrangements that affect them. ${ }^{60}$ The function of freedom is thus twofold: it empowers individuals in 
identifying and having the option to identify what they feel is important for their own development, but in doing so enables them to better engage with civil society, lobby for more suitable social arrangements, and ultimately better-shape their own future development. It is well that Sen does not perceive economic development as the end-point, considering Somalia's abject state failure and the economic collapse of the region as a whole.

This is not to say that Somalia is ready for any manner of large education and political development programme. Indeed, simply feeding Somalia and ensuring that the most basic of needs are met is of utmost importance in the short- to mediumterm. More to the point, empowering Somalia would require that citizens, irrespective of clan alliance, be included in the process, thus enabling them to understand and perceive their role in harnessing Somalia's future free from the harsher deprivations of famine and civil war. But in order to be able to responsibly give Somalis agency in their own development, it is important that they understand why transcending clan allegiance for the greater good is important for their own security, and likewise monitoring the more practical risk of black-market smuggling of aid must be enabled closely. In the 1990s, much of Somalia's food aid was stolen or raided, but this is a problem which can be overcome with sufficient supervision and mentoring, hopefully with the end result in that Somali humanitarian assistance administration will become self-regulating. ${ }^{61}$

\section{Feasibility}

It must be emphasised that this kind of ambitious post-conflict assistance is only feasible in the slightest degree under an effective "security net" as argued previously. If UNOSOM has taught the UN anything, it is the dangers of attempting to open and maintain channels of humanitarian assistance in Somalia without adequate security frameworks. If humanitarian assistance continued to be disrupted in the manner of UNOSOM's missions, as well as NGO's own independent initiatives, because of a lack of peacekeepers and a hostile population, the entire spirit of assistance is undermined.

This has already occurred, given the recent attacks on Médecins sans Frontières' personnel and others; but with a redoubled effort at large-scale military protection of humanitarian assets, the goodwill of the Somali people can for the most part be won back. ${ }^{62}$ This has the dual benefit of enabling lead acting states such as the United States or other major NATO members to provide military assistance to humanitarian organisations while allowing smaller states the option of providing financial aid necessary for the humanitarian track without concerns of the safety of either funds or citizens. This duality of responsibility is done on an ad hoc basis of 
pledges and promises historically, and has proven to have failed spectacularly in UNOSOM as states hung back, waiting to see how the situation would improve or worsen. $^{63}$

Why justice for war can help Somalia

The spirit of R2P has become obscured by the series of failures seen in Somalia. With the recent AMISOM intervention, the limitations of such a restricted and ill-equipped force is indicative of just why Somalia's hope for an end to conflict cannot emerge quickly or effectively. ${ }^{64}$ But this need not be the case. Should the US or UN Security Council's respective administrations ever garner the political will necessary to intervene in Somalia again, it is crucial to bear in mind that the precedents set by the decisive military failures to enforce peace in 1993 are by no measure an indication of certain doom for any future force. As argued above, military intervention is not only justified by criteria laid out not only in international law, but in the roots of "just-war" philosophy. Furthermore, if military intervention can be carried out on a large enough scale as to match the strategic requirements, and with a broad enough mandate to secure the region, reinforcing existing channels for humanitarian aid becomes a logical second step. Essentially, one of the largest objections used by state leaders to absolve responsibility to get involved in Somalia is that of military unfeasibility, citing the 1992/3 UNOSOM operations as a prime example of how even the United States can fail militarily. But on closer examination, we see that not only is this pretence false, it is ignorant of the broader failings of the Security Council in creating a sound strategy before boots even touched the ground in Mogadishu.

Military intervention in Somalia can be achieved, and moreover it is completely within the bounds of moral justification for the deployment of forces. More importantly, securing Somalia would enable the kind of humanitarian assistance so crucial for securing the failed state and providing a framework for eventual elections processes, it would de-escalate tensions with neighbouring states such as Ethiopia and Eritrea, and would ironically solve one of the international community's biggest maritime headaches: piracy in the Gulf of Aden. It would be naive to assume that such an intervention would be cheap or without cost. But much like the proportionality of jus ad bellum, understanding that the net utility of securing Somalia would outweigh the perceivable cost is the first step in eroding the lack of political will at the Security Council. 


\section{Endnotes}

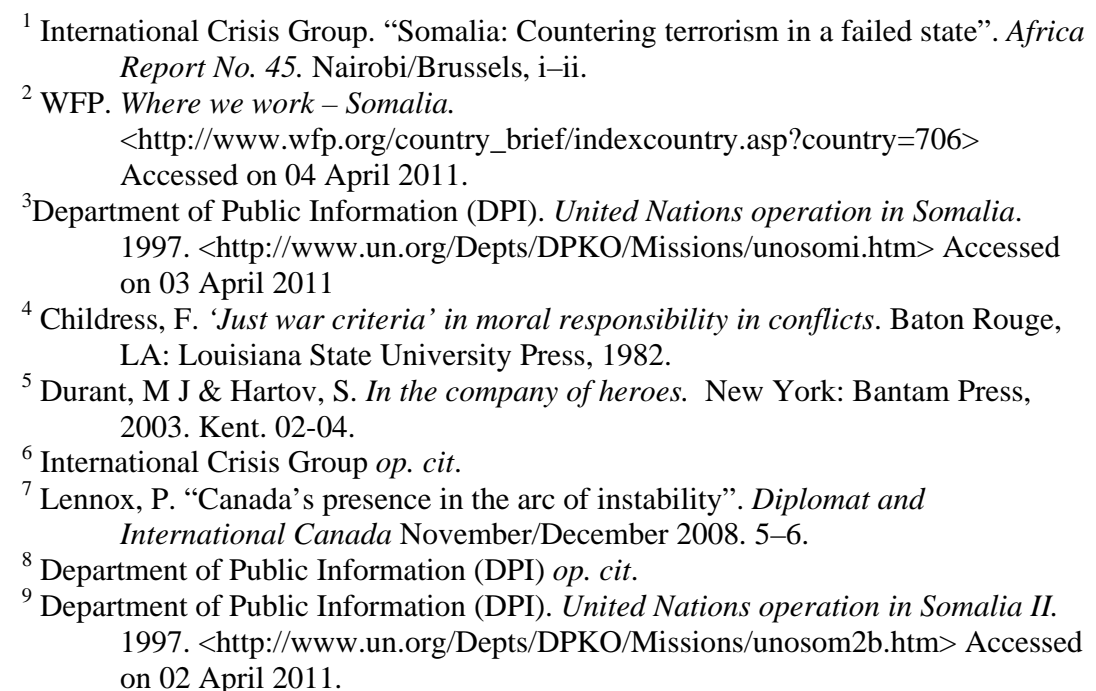

${ }^{10}$ Durant \& Hartov op. cit., pp. 216-222.

${ }^{11}$ Government Accountability Office (GAO). Several challenges limit US and international stabilization, humanitarian, and development efforts. February 2008, 15-17.

${ }^{12}$ National Security Council. Countering piracy off the Horn of Africa: Partnership and action plan. December 2008, 4. <http://www.globalsecurity.org/military/library/policy/national/0812_nsc_co unter-piracy-action-plan.pdf> Accessed on 05 July 2009

${ }^{13}$ Stanford University. Stanford Encyclopaedia of Philosophy. 28 July 2005. $<$ http://plato.stanford.edu/entries/war/\#2.2> Accessed on 25 July 2009.

${ }^{14}$ Corn, G. "For the sake of warriors: Accepting the limits of the law of war". JURIST. Pittsburgh, PA: Pittsburgh University, 2006.

${ }^{15}$ Stanford University op. cit.

${ }^{16}$ Kemp, K. "Just-war theory: a reconceptualization." Public Affairs Quarterly, 2 (2), April 1988. Pp02-03

${ }^{17}$ Walzer, M. Just and unjust wars. New York: Basic Books, 1977.

${ }^{18}$ Kane, B. Just war and the common good: Jus ad bellum principles in 20th century papal thought. San Francisco, CA: Catholic Scholars Press, 1997.

${ }^{19}$ United Nations. Security Council: $5858^{\text {th }}$ meeting, New York, March 2008, 3.

${ }^{20}$ Evans, G \& Sahnoun, M. "The responsibility to protect”. Foreign Affairs 83. 2002. 103-104.

${ }^{21}$ Ibid., p. 104.

${ }^{22}$ Middleton, R. "Piracy in Somalia: Threatening global trade, feeding local wars". Africa Programme. Chatham House, October 2008, 10. 
${ }^{23}$ Internal Displacement Monitoring Centre. Internal displacement: Global overview of trends and developments in 2007. April 2008. <http://www.internaldisplacement.org/> Accessed on 06 April 2011.

${ }^{24}$ Evans \& Sahnoun op. cit., pp. 103-104.

${ }^{25}$ Stanford University op. cit.

${ }^{26}$ Khadiagala, G. Eastern Africa: Security and the legacy of fragility. New York: International Peace Institute, October 2008, 4.

${ }^{27}$ International Crisis Group op cit., pp. 11-12.

${ }^{28}$ Evans \& Sahnoun op. cit., p. 106.

${ }^{29}$ Ibid., p. 108.

${ }^{30}$ Gwertzman, B. "Holbrooke: Kosovo independence declaration could spark crisis”. Council on Foreign Relations. December 2007.

$<$ http://www.cfr.org/publication/14968/holbrooke.html\#at> Accessed on 04 April 2011

${ }^{31}$ Pan, E. "United Nations: Nation-building”. Council on Foreign Relations. October 2003.

<http://www.cfr.org/publication/7755/united_nations.html\#at> Accessed on 05 April 2011

${ }^{32}$ United Nations Security Council. Resolution 1973, March 2011.

${ }^{33}$ Blokker, N. "Is the authorization authorized? Powers and practice of the UN

Security Council to authorize the use of force by'coalitions of the able and willing”

European Journal of International Law, 2000

${ }^{34}$ Stanford University. op. cit.

${ }^{35}$ International Crisis Group op. cit., pp. i-ii.

${ }^{36}$ Sahnoun, M. "Prevention in conflict resolution: The case of Somalia”. Irish Studies in International Affairs 5. 8-9.

${ }^{37}$ Commander, Combined Maritime Forces Public Affairs. "New counter-piracy task force established”. Navy Newsstand. January 2009. 01.

${ }^{38}$ Durant \& Hartov op. cit.

${ }^{39}$ Hull, C. \& Svensson, E. “African Union Mission in Somalia (AMISOM).

Exemplifying African Union Peacekeeping Challenges.” Swedish Defence Research Agency. Stockholm, Sweden. 2008.

${ }^{40}$ Bolton, J. "Wrong turn in Somalia”. Foreign Affairs 73/1. January-February 1994. 56-66.

${ }^{41}$ Sahnoun, op. cit., p. 11.

${ }^{42}$ Ibid.

${ }^{43}$ Bolton op. cit., pp. 59-60.

${ }^{44}$ Ibid., pp. 60-61.

${ }^{45}$ Ibid., p. 62.

${ }^{46}$ Ibid., p. 65.

${ }^{47}$ Miller, L. “The Clinton years: Reinventing US foreign policy?” Royal Institute of International Affairs 70/4. October 1994. p629.

${ }^{48}$ The Economist, 15 January 1994, 24. 
${ }^{49} \mathrm{Tal}, \mathrm{T}$. "Are the principles of war applicable to special task forces? Operation Gothic Serpent re-examined”. The RUSI Journal 154/2. April 2009. 56-62.

${ }^{50}$ Lennox op. cit., p. 5.

${ }^{51}$ Ibid.

52 Boot, M. "Pirates, then and now”. Foreign Affairs. July/August 2009. 90-109.

${ }^{53}$ Stanford University op. cit.

${ }^{54}$ Lennox op. cit., p. 15.

${ }^{55}$ WFP op. cit.

${ }^{56}$ Hanson, S. Somalia's perpetual war. New York: Council on Foreign Relations, May 2008.

${ }^{57}$ Sahnoun op. cit., pp. 8-9.

${ }^{58}$ Bolton op. cit., p. 57.

${ }^{59}$ International Crisis Group. Somalia: To move beyond the failed state. December 2008, 19-20.

${ }^{60}$ Sen, A. Development as freedom. New York: Anchor Books, 1999, 5-6.

${ }^{61}$ Sahnoun op. cit., p. 11.

${ }^{62}$ International Crisis Group. Somalia: To move beyond the failed state op. cit., p. 19.

63 Sahnoun op. cit.

${ }^{64}$ United Nations. Security Council: $5858^{\text {th }}$ Meeting, New York, March 2008, 8. 